\title{
DEVELOPING EQUITABLE ELEMENTARY CLASSROOM PLACEMENT ROUTINES
}

\author{
Kevin K. LURZ \\ Graduate Student, Department of Educational Leadership, Fresno State, California, United States \\ ORCID: https://orcid.org/0000-0002-7472-3485 \\ kevinlurz@mail.fresnostate.edu \\ Nichole WALSH \\ Assistant Professor, Department of Educational Leadership, Fresno State, California, United States \\ ORCID: https://orcid.org/0000-0003-1426-0551 \\ nwalsh@mail.fresnostate.edu
}

Received: December 13, $2021 \quad$ Accepted: February 08, $2022 \quad$ Published: June 30, 2022

Suggested Citation:

Lurz, K. K., \& Walsh, N. (2022). Developing equitable elementary classroom placement routines. International Online Journal of Primary Education (IOJPE), 11(1), 1-19. https://doi.org/10.55020/iojpe.1076761

(c) (7)

\begin{abstract}
The annual assignment of elementary students from one classroom to the next is a ubiquitous cycle in schools. Since student class assignment has an effect on students' educational trajectory, understanding how placement procedures impact student equity is an important area of research with benefits for all stakeholders. In this action research project, survey data was collected to examine what student data points teachers found most meaningful as well as what elements participants considered the most effective and the least beneficial components of the previous piloted placement procedures at a central California elementary school. The findings of this research demonstrated that respondents valued intervention data, such as English Language Proficiency Assessments for California (ELPAC) levels or special education (SPED) status, English Language Arts (ELA)/Math achievement data, and behavior data. However, they also expressed hesitancy over certain narrative or subjective information. Respondents also reported that, while multi-grade level cooperation was a valuable component of the placement process, the procedures needed to be more clearly systematized. Findings suggest that by linking placement procedures to existing Multi-Tiered System of Supports (MTSS) structures, the placement process can more effectively address issues of student equity and achievement.
\end{abstract}

Keywords: Student placement procedures, equity, achievement, multi-tiered systems of support, general systems theory.

\section{INTRODUCTION}

According to the federal agency tasked with collecting and analyzing educational data, nearly four million students were expected to begin kindergarten in the Fall of 2020 (U.S. Department of Education, n.d.). During each of the next six years of their school career, the vast majority of these students will be promoted to their next grade level, a process that will annually group and regroup them into cohorts and assign them to (usually) a new teacher. The placement of students into these groups and assigning them to a new teacher is fraught with significant effects on both the short- and long-term trajectory of a student (Bosworth \& Li, 2013; Burns \& Mason, 1995; Park, St. John, Datnow, \& Choi, 2017; Sleenhof, Koopman, Thurlings, \& Beijaard, 2019).

This placement process is primarily directed at the school site level, typically with minimal direction from the district. Administrator training programs also rarely address student placement and the formation of classes (Paufler \& Amrein-Beardsley, 2014). Not surprisingly, profound variations exist between schools and educators regarding how placement procedures are undertaken (Burns \& Mason, 1995). Having a regularly recurring, predictable, and ubiquitous process that has potentially profound effects on a students' achievement without direction from the training institutions or districts presents an essential area for further research.

In this project, the researcher sought to understand who makes decisions about placement procedures and what factors play into their decision-making process. Understanding how the context of decision- 
makers (such as local socioeconomics, community demographics, or school size) also affected the way placement decisions are made. While principals often play a defining role, teachers also regularly weigh heavily in the process (Paufler \& Amrein-Beardsley, 2014). The conditions set for educators' involvement also contribute to how the conversations and decisions made during the process occur (Sleenhof et al., 2019).

Site conditions also determine how data are collected and utilized to make placement decisions. Data use has substantial implications for equity in many areas of education, and placement procedures are no exception (Datnow \& Park, 2018). Data literacy plays a role in determining what student data will be prioritized and interpreted (Mandinach \& Gummer, 2016; Park et al., 2017). Mitigating these variances to improve placement results is an important subject in much of the literature. Suggestions for doing so include improving meeting facilitation (Sleenhof et al., 2019), using computer-based applications to limit participant data and micropolitical stresses (Krauss et al., 2013), and regularly training staff to use data with an equity mindset (Mandinach \& Gummer, 2016). Reflective practices are also integral to improving this system (Bens, 2012; Buffum et al., 2018; Conzemius \& O'Neill, 2014; DuFour, DuFour, Eaker, Many, \& Mattos, 2016). Through feedback and direct training, research has demonstrated that capacity building will work to improve equitable data use at the site.

Previous research has shown that optimizing these routines has the potential to improve student achievement (Buffum, Mattos, \& Malone, 2018; DuFour et al., 2016; Mandinach \& Gummer, 2016; Sleenhof et al., 2019). Refining student placement procedures will lead to improved measures of student achievement and a more strategic allocation of resources. Thus, it behooves all school districts and sitelevel leaders to reflect on their student placement procedures with an eye on equitable practices.

\section{Purpose of the Study}

The purpose of this study was to understand better how issues of equity are linked to classroom placement procedures and how, in turn, such procedures should be improved to encapsulate and promote equitable practices at the school site. While the scope of this project focuses on a single placement cycle at a single suburban elementary school in central California, it is the researcher's intent that understanding the procedures at this location will provide greater insight that can be extrapolated and generalized to similar settings through a tool to guide systematic placement procedures.

Next, this research project intended to better understand what elements of the placement process the teacher and administrator participants considered a benefit, a hindrance, or in need of improvement. While educator opinions on these topics might not indicate any objectively credible point of contention, they nevertheless remain useful in revealing trends in how the process was carried out. This may, in turn, have implications for practice. For example, if multiple participants noted that meetings generally wasted time or meandered, this might imply that the procedures themselves may need to be made more efficient. This subjective information might also indicate problems in the way placement procedures are facilitated. If survey respondents routinely noted issues of favoritism during placement procedures, this may demonstrate problematic micro-political decisions or a lack of transparency which could undermine stakeholder faith in the process at large. All these considerations have implications for equity at the school site and thus need to be discerned for their potential effect on stakeholders.

\section{Review of the Literature}

Although millions of elementary students are annually grouped and placed in their next classroom, researchers studying the subject commonly express concern about the procedures, philosophies, and priorities for this ubiquitous and perpetual process (Bosworth \& Li, 2013; Burns \& Mason, 1995; Kalogrides, Loeb, \& Béteille, 2013; Park et al., 2017; Sleenhof et al., 2019). In studying student placement procedures in one southern state, Bosworth and $\mathrm{Li}$ (2013) note that little is known about how classroom assignment carries across schools. Likewise, St. John (2014) acknowledges that little research has been done on this context in elementary schools, especially to uncover how student placement procedures relate to stakeholder and school leadership concerns regarding teacher evaluation, student achievement, and educational equity. Still, a small body of literature exists that begins to address 
this complex topic from several directions, including the procedures, decision makers, outcomes, and how student data are utilized to move students from one grade to the next.

Further complicating the issue are the wide divergences in how such student placement procedures are carried out. Burns and Mason (1995) found that student assignment procedures vary according to the organizational context of the site, even within the same district, and that these variations have a noticeable effect on stakeholders. These variations present an essential area of study for researchers because the ramifications for stakeholders engaged in the process are significant. Researchers Park et al. (2017) interviewed teachers and school leaders in elementary schools on annual placement routines and also found that such procedures have important implications for equity and access to quality instruction. Similarly, Kalogrides et al. (2013) examined class-assignment patterns using eight years of data from administrative files in the Miami-Dade County Public School district and found systemic inequities in how students were assigned to their teachers specifically noting the positive correlation between teacher experience and student achievement related to placement indicating lower achieving students more likely to be placed with less experienced teachers. Furthermore, Kalogrides et al. (2013) found that in schools led by white administrators with a majority of white teachers on staff, the aforementioned demographic equity gaps are more prominent. While they did not find any specific causation for such disparities in student assignment, they observed that these patterns likely result from the personal biases and assumptions of school leadership, as well as teacher and parental preference (Kalogrides et al., 2013). Unfortunately for students within these school contexts, Kalogrides et al. (2013) observed that structural factors would continue to widen gaps for underserved students as newer teachers tend to have less efficacy than their more experienced peers, while inequitable grouping serves to increase teacher turnover rates.

Based on the above studies, student achievement and demographic data are clearly prioritized when making student classroom placement decisions with potentially devastating results. However, Datnow and Park (2018) note that studies have failed to move beyond those factors. They argue that social justice, equity, and the use of data are integrally bound to one another (Datnow \& Park, 2018). Thus, understanding the processes and contexts of student placement decisions in greater detail is important for educational leaders in that it can potentially illuminate areas in which gaps in student achievement and equity may be redressed.

\section{Theoretical Framework}

Originally developed to explain biological relationships and metabolic processes, general systems theory was later broadened in scope and applied to fields like business management or education (Sauter, 2017). General systems theory centers on the understanding of a particular process in which input is transformed into a desired output via the relationship between various elements or subsystems contained within the system (Caws, 2015).

This framework is applicable to this research project because the procedures for moving a group of students from one grade to the next similarly involve input (student data), a set of subsystems or elements (data analysis, placement meetings), and a desired output (balanced, heterogeneous classrooms that promote equity). Using general systems theory in this research project will help illuminate the elements and subsystems that effectively lead to the desired outputs, and which of those elements or subsystems inhibit the desired output from occurring. Placement procedures involve a complex set of interactions between educators that require systemic thinking to sort, prioritize, and manage in order to make the optimal placement choices for students.

Lastly, general systems theory acknowledges problems associated with closed systems. Closed systems, defined as those systems that fail to accept input, eventually fall into entropy and collapse (Caws, 2015; Vornberg, 2013). While student data are one input into the system of student placement procedures, in order for placement systems to remain relevant and effective they also need to accept reflective input that is explicitly purposed to improve the elements of the system. Cycles of improvement, driven by participant reflection and input, are integral for maintaining effective educational systems (Buffum et 
al., 2018; Conzemius \& O'Neill, 2014; DuFour et al., 2016). Therefore, a reflective element must be an integral component of placement procedures in order to provide germane feedback that improves and refines how stakeholders are being served.

\section{Research Questions}

This research study aimed to answer the following two questions:

1. How does the process of elementary students' classroom placement relate to issues of educational equity?

2. How can the classroom placement process be improved to promote both equitable instructional practices and improved student achievement?

\section{METHOD}

Collecting relevant quantitative and qualitative survey data from participating school educators was critical to this action research study to better under which student data points participating considered most critical to the placement process. With 26 data points per student to consider during the 2020 placement cycle at the research site, the researchers hoped to create a more relevant and focused set of parameters for future placement consideration. Figure 1 provides the 25 data points by category for reference in the order of the referenced student placement procedure.

\begin{tabular}{|c|c|c|c|c|}
\hline $\begin{array}{l}\text { Special Education } \\
\text { and Intervention }\end{array}$ & $\begin{array}{c}\text { Academic } \\
\text { Achievement }\end{array}$ & Behavior & Engagement & $\begin{array}{c}\text { Demographic \& } \\
\text { Categorical }\end{array}$ \\
\hline $\begin{array}{c}\text { IEP } \\
\text { Speech } \\
504 \\
\text { SST } \\
\text { Reading } \\
\text { Intervention } \\
\text { English } \\
\text { Language } \\
\text { Assessment }\end{array}$ & $\begin{array}{l}\text { ELA \& Math } \\
\text { State } \\
\text { Achievement } \\
\text { Reading } \\
\text { Benchmark } \\
\text { Lexia Core \& } \\
\text { Power Up Score } \\
\text { STAR Reading } \\
\text { \& Math Score }\end{array}$ & $\begin{array}{c}\text { Level of } \\
\text { Behavioral } \\
\text { Support } \\
\text { Existing } \\
\text { Behavioral } \\
\text { Supports } \\
\text { Previous } \\
\text { Teacher Notes } \\
\text { Peers Not to } \\
\text { Be/To BePlaced } \\
\text { With }\end{array}$ & $\begin{array}{c}\text { Number of } \\
\text { Absences \& } \\
\text { Tardies } \\
\text { Level of } \\
\text { Parental } \\
\text { Involvement } \\
\text { Level of } \\
\text { Distance } \\
\text { Learning } \\
\text { Engagement* }\end{array}$ & $\begin{array}{l}\text { Counseling } \\
\text { Services } \\
\text { Gender } \\
\text { Wears Glasses }\end{array}$ \\
\hline
\end{tabular}

Figure 1. Data points by category in placement procedure order

\section{Research Site Context}

The research concerned the 2020 student placement procedures at one public charter school in California's Central Valley. The school is a kindergarten through grade eight public community charter school operating as part and under the authority of one large preschool through high school urban, suburban and rural serving school district. The school has an enrollment of approximately 432 students with nearly $80 \%$ considered socioeconomically disadvantaged (SED) and close to $26 \%$ classified and English learners., according to publicly available data through the California Department of Education (CDE, n.d.) website. In terms of student race and ethnicity, CDE (n.d.) reports the students at the research school are 79.2\% Hispanic, 13.4\% White, 3.5\% Asian, 1.4\% Two or More Races, $1.2 \%$ African American, and less than $1 \%$ American Indian and Filipino (CDE, n.d.).

Prior to becoming a charter, the school operated as a traditional community-based elementary school until new larger community elementary school campus was opened by the district less than a mile away. In 2017, the research site school was then repurposed as a district community charter with several distinct differences from the district's typical elementary school. First, each classroom after kindergarten is a multi-grade classroom grouping students to learn together as follows: first/second, third/fourth, fifth/sixth, and seventh/eighth. Additionally, the assigned teacher for each respective group 
loops with the same students over a 2-year period instead of being assigned a different set of student annually as is common with the traditional model. The charter school also employs a variety of curriculum resources outside of those adopted by the district. According to the charter documents, the school mission is to differentiate itself by focusing on project-based learning, community service, cooperative cross-age learning, a high level of technology integration, 21st-century skills, global education, and a Spanish language program for all kindergarten through eighth-grade students (Unified School District, n.d.).

\section{Survey Instrument}

Participant feelings and perceptions on the previous year's student placement cycle procedure were gathered using a 29-item electronic survey. The first set of questions consisted of 26 anchored rating questions asking respondents to consider the usefulness of the respective 26 student data points used in the 2020 placement process. Three open-ended questions aimed at understanding participant teacher perceptions of the 2020 placement process. The questions centered on what teachers felt were most helpful/productive, least helpful/productive, and what aspects of future placement cycles could be improved with explanation.

\section{Participants}

Seventeen participants consisting of fifteen teachers and two administrators were purposively sampled according to the following criteria: participation in the 2020 student placement process at the school site being researched. All participants still worked at the school site, except for one administrator who worked in the same district at a different school and one teacher who had recently retired but still lived in the immediate area with regular staff contact. Teachers and administrators currently at the site who were not involved in the 2020 student placement process will not be participating in the survey.

\section{Data Collection}

Participants were sent an email containing an overview of the study purpose and goals and a link to the survey. The recruitment email also included researcher contact information regarding concerns or questions about the study. The survey included informed consent as the initial question and participants were only able to continue with the survey after assenting to the language in the consent form. Weekly email reminders were sent out over a 4-week period in order to increase participation rates.

\section{Data Analysis}

This study relied on descriptive statistical analysis open thematic coding (DePaolo \& Wilkinson, 2014) in order to understand the concepts, themes, and patterns that develop through the course of previous placement practices. The anchored rating survey questions were analyzed descriptively using frequency and means in order to broadly understand what student data were most important to educators during the placement cycle, as well as understand how the perceived importance of student data points was distributed amongst teachers. Open ended response data were used to understand what other placement data points might add value to placement process as well as to draw conclusions to inform the placement process revisions. Open ended response data were given inductive codes during the first-stage, open coding process to identify aspects of the placement process that were helpful or not helpful. Next, these codes were refined during the second-stage coding process to generate a broad list of attributes to describe current processes and to guide future placement procedures. From here data were given descriptive themes via open, thematic coding aided by word clouds to assist in identifying potential trends (DePaolo \& Wilkinson, 2014). The overall goal of these staged analyses was to understand which aspects of the placement process were perceived to be extraneous hindrances versus those vital to the educators involved for enacting equitable student class placement outcomes.

\section{Validity and Reliability}

Regarding qualitative survey data, intercoder reliability (Johnson \& Christensen, 2019) will be maintained because a single researcher conducted all analysis during the thematic coding process with code checking for cognitive drift completed by the second researcher. Internal consistency (Johnson \& Christensen, 2019) will be further facilitated with the aid of electronically generated word clouds to 
identify essential ideas or phrases by frequency of use that the researcher may have otherwise overlooked (DePaolo \& Wilkinson, 2014).

Validity for the Quantitative survey data will be addressed first via construct reliability (Johnson \& Christensen, 2019) from relevant research literature in order to inform the analysis of the descriptive trends. The anchored rating item validity will be reinforced as each question refers to a distinct student data point used by the participants during the most recent 2020 student classroom placement cycle. The survey also had a high response rate of $88.24 \%$, which increased overall study validity and reliability with strong representativeness of the research context (Fincham, 2008).

\section{RESULTS}

The survey results based on the feelings and experiences with the 2020 student classroom placement procedures at one small public community elementary charter school in California's Central Valley highlighted the data points educators found most and least important as well as ways the process could be improved. Respondents often cited intervention statuses, behavior support levels, language arts achievement, and math achievement as primary concerns for placement, while engagement and computer-based assessments were noted as less applicable. Open-ended responses yielded data regarding why specific data points were prioritized over other data points, as well as concerns over how placement meetings were organized in the past. Respondents overwhelmingly valued collaborative environments while simultaneously feeling such meetings were also fraught with biases and micropolitical maneuverings that negatively affected fair and equitable placement.

\section{Descriptives}

In the first section of the survey, educators were asked to rate how useful they perceived specific student data points during the formation of new classes. Each student data point included in the survey corresponded to a student data point used during the 2019-2020 placement cycle. The educator responses were measured according to a scaled response score of 1 through 5 . A score of 1 indicated that the respondent found the data "not useful" during the placement process, whereas a score of 5 indicated a particular student data point was considered "most useful." This survey information was informative for answering the research questions for this case study because it indicated how educators involved in the 2019-2020 placement cycle prioritized specific demographic, academic, intervention, or behavioral student information.

By understanding what information was most critical to educators during the decision-making process, the system for student placement could be streamlined to include only the most useful criteria. Potentially, redundant or overlapping data could be removed in order to simplify the creation of balanced, heterogeneous classes. Furthermore, these survey data are vital because they reflect the current thinking of teachers at the site regarding student equity. By more clearly understanding what student attributes teachers considered most important, the procedures for classroom placement could be modified accordingly to promote equitable practices.

Specifically, the quantitative findings are presented below, through frequencies and means, in the order of greatest perceived applicability and usefulness to those considered less useful in the placement process. The data points are likewise grouped into thematically related categories. Special education status and academic interventions have been grouped together because they represent either specific legally mandated interventions, such as special education status, or site-based initiatives such as enrollment in reading intervention classes. The category of academic achievement data refers to any student data points that indicate their level of standards-based performance. Behavioral data refers to student data points that discuss a student's disciplinary record or classroom conduct. Student engagement refers to any student data points that track a student's attendance or level of commitment to schoolwork. Demographic or categorical data refers to student information that is not attributable to classroom factors, such as gender or enrollment in counseling services. 


\section{Special education and academic intervention status}

Of the 25 data points used during the placement process, survey respondents tended to rate special education and academic intervention status relatively high. Of the highest survey rankings, five of the seven fell under this category of student data (see Table 1). Student IEP status, determined by their enrollment in SPED services, was the highest-ranked student data point of the 25 in the survey $(M=$ $4.73, \mathrm{SD}=.458$ ). While IEP status may indicate the student's receiving of either behavioral or academic SPED services, it was differentiated in the placement process from IEPs related to Speech services. Speech services, while still rated highly by a majority of educators, had a much lower mean and a greater standard deviation than non-speech IEPs $(\mathrm{M}=3.80, \mathrm{SD}=1.373)$. Speech IEPs were ranked 11th of 25 student data points. Student ELPAC score was the second-highest mean score for any student data point $(\mathrm{M}=4.53, \mathrm{SD}=.516)$.

Table 1. Frequencies, means, and standard distributions of special education and intervention data point rating responses

\begin{tabular}{lccccccc}
\hline Data Point & $\begin{array}{c}f \\
\text { Score 1 }\end{array}$ & $\begin{array}{c}f \\
\text { Score 2 }\end{array}$ & $\begin{array}{c}f \\
\text { Score 3 }\end{array}$ & $\begin{array}{c}f \\
\text { Score 4 }\end{array}$ & $\begin{array}{c}f \\
\text { Score 5 }\end{array}$ & Mean & SD \\
\hline IEP & 0 & 0 & 0 & 4 & 11 & 4.73 & .458 \\
Speech & 1 & 2 & 3 & 2 & 7 & 3.80 & 1.373 \\
$\mathbf{5 0 4}$ & 0 & 0 & 1 & 5 & 9 & 4.53 & .670 \\
SST & 0 & 1 & 2 & 5 & 7 & 4.20 & .941 \\
Reading Intervention & 0 & 0 & 2 & 8 & 4 & 4.14 & .663 \\
ELPAC Level & 0 & 0 & 0 & 7 & 8 & 4.53 & .516 \\
\hline
\end{tabular}

While IEPs are a legal function of the federal government's 1990 Individual with Disabilities Acts, student 504s originate from Section 504 of the Rehabilitation Act of 1973. Student 504s are differentiated from IEPs in terms of what disability they are addressing and whether a student requires accommodations (504) or modifications (IEP) for student success in the learning environment. While IEPs address 13 specific disabilities listed in the IDEA act, 504 plans address any disability that may interfere with a student's learning (Understood for All, n.d.). Student 504 status was the second-highest ranked student data point $(\mathrm{M}=4.53, \mathrm{SD}=.670)$, tying with student ELPAC level in order of perceived importance to teachers.

The data point SST referred to whether a student had previously or currently been involved in a Student Study Team. Experiences with SSTs are often a precursory process before SPED status is determined and was likewise reflected in its relatively high ranking $(\mathrm{M}=4.20, \mathrm{SD}=.941)$. Student Study Teams can also refer students to other services, like behavioral supports or non-SPED interventions, as warranted by the students' particular needs. The SST status was the sixth most essential student data point as determined by the mean score of the survey answers.

Reading intervention refers to a site-level intervention program wherein students who fall behind in their reading achievement level meet regularly in small groups with a reading specialist. These groups are flexible, although some students may spend most of the year in such groups to get them closer to proficiency. There are no set guidelines or criteria for referring students to reading intervention at the site, although maintaining a small intervention group size sets a cap on the number of students who can attend. Because these services are not legally mandated or controlled by district policy like SPED, SST, or 504 plans, non-academic attributes such as student behavior and work habits are often contributing factors considered before sending a student to reading intervention. A student's involvement in the sitelevel intervention group ranked seventh on the list of 25 student data points, with most teachers ranking it as a 4 or $5(\mathrm{M}=4.14, \mathrm{SD}=.663)$. 
During the 2019-2020 placement procedures, teachers reported whether a student was classified as an English Learner student by indicating their current ELPAC level. For non-EL students, the response was left blank. Besides the ELPAC's four reporting levels, teachers could also respond if a student had been listed as "fluent" or "reclassified" or "pending." Teachers overwhelmingly reported a student's EL status and ELPAC score to be of considerable importance, with all respondents marking it as a 4 or $5(\mathrm{M}=4.53, \mathrm{SD}=.516)$.

\section{Academic achievement data}

Several data points used in the class formation process were measures of student achievement. These measures varied with regards to their applicability for particular grade levels and their possible level of subjectivity. Student ELA and Math levels were ranked as the ninth and tenth most useful data points (as measured by their score means), with nearly identical distributions of response frequencies and standard deviations (see Table 2).

Table 2. Frequencies, means, and standard distributions of academic achievement data point rating responses

\begin{tabular}{|c|c|c|c|c|c|c|c|}
\hline Data Point & $\begin{array}{c}f \\
\text { Score } 1\end{array}$ & $\begin{array}{c}f \\
\text { Score } 2\end{array}$ & $\begin{array}{c}f \\
\text { Score } 3\end{array}$ & $\begin{array}{c}f \\
\text { Score } 4\end{array}$ & $\begin{array}{c}f \\
\text { Score } 5\end{array}$ & Mean & SD \\
\hline ELA Level & 0 & 2 & 3 & 4 & 6 & 3.93 & 1.100 \\
\hline Math Level & 0 & 2 & 3 & 5 & 5 & 3.87 & 1.060 \\
\hline BAS Level & 0 & 3 & 3 & 4 & 5 & 3.73 & 1.163 \\
\hline Lexia Core 5 Level & 3 & 2 & 7 & 3 & 0 & 2.67 & 1.047 \\
\hline STAR Reading Score & 2 & 3 & 7 & 2 & 0 & 2.64 & .929 \\
\hline STAR Math Score & 2 & 3 & 7 & 2 & 0 & 2.64 & .929 \\
\hline Lexia Power-Up Level & 4 & 2 & 7 & 1 & 0 & 2.36 & 1.008 \\
\hline
\end{tabular}

When educators entered these data points into the spreadsheet used to disaggregate the data, there were no guidelines or rubrics presented to align scores across or within grade level spans. These ELA and Math scores used a four-point scale that corresponded to the language and scoring used on the site's standards-based report card. Scores for ELA and Math achievement were 1 for below standard, 2 for standard nearly met, 3 for standard met, and 4 for standard exceeded.

The BAS level refers to Fountas \& Pinnell's Benchmark Assessment System. This reading benchmark assessment is only used by the site's kindergarten and first/second grade span teams. It is administered by a teacher at the site three times a year to measure each kindergarten through second-grade student's instructional reading level. Each reading level is given an alphabetic code that corresponds to a Lexile level. The mean score of BAS ranked $12^{\text {th }}$ out of 25 data points according to the mean score on the survey. The distribution and standard deviation for BAS level were similar to Math and ELA achievement scoring. In terms of reading assessments, BAS level ranked far higher than all others.

The STAR Reading and Math assessments were both developed by the Renaissance Learning company. Unlike the BAS reading assessment, the STAR tests are fully online and do not require a human proctor. These assessments themselves take a similar amount of time as the BAS and provide a variety of measures and reports for teachers. For the STAR Reading assessment, teachers can measure students according to various scoring metrics such as their Grade Level Equivalent score, Instructional Reading Level, Lexile level, STAR scales, PARCC score, and percentile ranking. For the site's 2019-2020 placement cycle, teachers reported students' Instructional Reading Level. For the STAR Math assessment, teachers can measure students according to such metrics as their Grade Level Equivalent 
scores, PARCC scores, percentile ranking, or Smarter Balance scoring. For the site's 2019-2020 placement cycle, teachers reported students' Grade Level Equivalent scores. Like BAS, each of these STAR tests is given three times a year at the site. According to the survey data, STAR Reading and STAR Math assessments mean scores tied for 20th place $(\mathrm{M}=2.64, \mathrm{SD}=.929)$ regarding their perceived usefulness in student placement. STAR math and STAR reading had identical means, standard deviations, and score distributions.

The remaining measures of student academic achievement used during the site's placement cycle is Lexia Core 5 and Lexia PowerUp levels. Lexia is a digital reading instruction platform that consists primarily of independent student practice that is supplemented with program-prescribed teacher reteaching and paper-and-pencil worksheets. Lexia Core 5 is intended to be used by grades one through five, while Lexia PowerUp is intended for grades six through eight. Each student is given a numerical level based on a preliminary digital assessment and their progression through the program. At GLC, Lexia Core 5 is used by grades one through five, Lexia PowerUp is used by grades five through eight, with overlap between programs occurring in the five/six grade span. The mean score for Lexia Core 5's perceived usefulness $(\mathrm{M}=2.67, \mathrm{SD}=1.047)$ rated slightly higher than either STAR assessment $(\mathrm{M}=$ 2.64, $\mathrm{SD}=.929)$, while Lexia PowerUp $(\mathrm{M}=2.36, \mathrm{SD}=1.008)$ ranked near the bottom of the list. Similar to the STAR assessments, the frequency scores both weighed heavily in the middle, with the most common respondent score being 3 in the case of each Lexia and STAR data point.

\section{Behavioral Data}

Student data corresponding to their behavior was generally ranked high as an essential data point for placement by survey respondents, with two exceptions. During the 2019-2020 student placement cycle, Students Level of Behavioral $(\mathrm{M}=4.33, \mathrm{SD}=1.047)$ support mean score was ranked fourth out of 25 student data points with regards to its perceived usefulness to educators (see Table 3).

Table 3. Frequencies, means, and standard distributions of behavioral data point rating responses

\begin{tabular}{lccccccc}
\hline & $\begin{array}{c}f \\
\text { Score 1 }\end{array}$ & $\begin{array}{c}f \\
\text { Score 2 }\end{array}$ & $\begin{array}{c}f \\
\text { Score 3 }\end{array}$ & $\begin{array}{c}f \\
\text { Score 4 }\end{array}$ & $\begin{array}{c}f \\
\text { Score 5 }\end{array}$ & Mean & SD \\
\hline $\begin{array}{l}\text { Level of Behavioral } \\
\text { Support }\end{array}$ & 0 & 2 & 0 & 4 & 9 & 4.33 & 1.047 \\
$\begin{array}{l}\text { Existing Behavioral } \\
\text { Supports }\end{array}$ & 0 & 1 & 4 & 3 & 7 & 4.07 & 1.033 \\
$\begin{array}{l}\text { Previous Teacher } \\
\text { Notes }\end{array}$ & 1 & 6 & 2 & 5 & 1 & 2.93 & 1.163 \\
$\begin{array}{l}\text { Peers Not To Be } \\
\text { Placed With }\end{array}$ & 0 & 2 & 1 & 3 & 9 & 4.27 & 1.100 \\
$\begin{array}{l}\text { Peers to Be Placed } \\
\text { With }\end{array}$ & 2 & 0 & 9 & 2 & 2 & 3.13 & 1.125 \\
\hline
\end{tabular}

Teachers were asked to rate students according to a four-tiered ranking system with the categories being model, manageable, constant redirection, and intense support. Despite the lack of any rubric or criteria for such categories, all but two respondents ranked this particular student data point as a 4 or 5 .

Teacher notes on existing behavioral supports also ranked relatively high $(\mathrm{M}=4.067, \mathrm{SD}=1.033)$, coming in eighth out of 25 student data points. These teacher notes most often referred to interventions put in place as part of the school's Positive Behavior Intervention and Support system. Such interventions could take the form of checking in with an adult on campus at the start and end of the school day, being given short breaks away from the classroom for emotional cooldown periods, or charts used to set goals and track a student's on-task behavior. In terms of behavioral data, behavioral supports $(\mathrm{M}=4.07, \mathrm{SD}=1.033)$ ranked above previous teacher notes $(\mathrm{M}=2.93, \mathrm{SD}=1.163)$ and peers with whom 
the student should be placed $(\mathrm{M}=3.13, \mathrm{SD}=1.125)$, but below the level of behavioral support and peers with whom the student should not be placed $(\mathrm{M}=4.27, \mathrm{SD}=1.100)$.

Juxtaposed to the relative importance of behavioral levels and types of behavioral supports was the relatively low mean score of the perceived usefulness of the previous teacher's notes $(\mathrm{M}=2.93, \mathrm{SD}$ $=1.163)$. Teacher notes $(\mathrm{M}=2.93, \mathrm{SD}=1.163)$ ranked 17 th out of 25 data points. The frequency of answers with these data was split down the middle, with six respondents giving teacher notes a score of 4 or 5 and seven respondents giving teacher notes a score of 1 or 2 (two respondents gave it a middle score of 3). Teacher notes varied with regards to length, descriptiveness, and focus. No guidelines or criteria were given during the placement process with regards to how or when such notes should be made.

Teachers involved in the 2019-2020 placement cycle at GLC were also asked to list names of individuals with whom the particular student should be placed, such as to be a support with language needs, and list individuals with whom the student should not be placed with, such as those who might exacerbate negative behaviors or increase the likelihood of conflict. Families would also request that their student be placed with or away from siblings and other family members, a particular concern in a smaller school with multi-grade classrooms. Other than honoring such family requests, there was no rubric or metric for how an individual should be listed. Each category, while somewhat related, resulted in very different responses to the survey. The mean score of listing students with whom the student should be placed with ranked $15^{\text {th }}$ out of 25 data points $(\mathrm{M}=3.13, \mathrm{SD}=1.125)$, while listing students that an individual should not be placed with ranked fifth out of 25 data points $(\mathrm{M}=4.27, \mathrm{SD}=1.100)$.

\section{Engagement Data}

Engagement-related student data refers to four data points used during GLC's 2019-2020 placement process that dealt with how students were engaged in the classroom. While these data points tangentially relate to student behavior, they are variables with contributing factors primarily taking place outside of the boundaries and control of the school. The mean score for all four of these data points ranked in the lower half of the survey (see Table 4). While absences and tardies were objective data sources, student and parental engagement were subjectively assessed by the teacher without any sort of rubric or metric.

Table 4. Frequencies, means, and standard distributions of engagement related data point rating responses

\begin{tabular}{lccccccc}
\hline $\begin{array}{l}\boldsymbol{f} \\
\text { Data Point }\end{array}$ & $\begin{array}{c}\boldsymbol{f} \\
\text { Score 1 }\end{array}$ & $\begin{array}{c}\boldsymbol{f} \\
\text { Score 2 }\end{array}$ & $\begin{array}{c}\boldsymbol{f} \\
\text { Score 3 }\end{array}$ & $\begin{array}{c}\boldsymbol{f} \\
\text { Score 4 }\end{array}$ & Score 5 & Mean & SD \\
\hline $\begin{array}{l}\text { Number of absences } \\
\text { Number of tardies }\end{array}$ & 2 & 4 & 2 & 6 & 1 & 3.00 & 1.254 \\
$\begin{array}{l}\text { Level of parental } \\
\text { involvement }\end{array}$ & 5 & 3 & 4 & 3 & 0 & 2.22 & 1.175 \\
$\begin{array}{l}\text { Level of distance } \\
\text { learning engagement }\end{array}$ & 4 & 4 & 11 & 0 & 1 & 2.87 & .834 \\
\hline
\end{tabular}

Teachers were asked to numerically note students' absences and tardies, taking these data directly from the school's database. The perceived usefulness of student absences during the placement process was ranked $16^{\text {th }}$ out of 25 data points, the highest-ranking for engagement-related student data $(M=3.00$, $\mathrm{SD}=1.154)$. The number of student tardies, on the other hand, ranked near the bottom at 24th of 25 , with the majority of respondents giving it a score of 1 or $2(\mathrm{M}=3.13, \mathrm{SD}=1.125)$. While a single teacher ranked absences as "most useful," no teacher did so with tardiness.

The mean score of parental engagement ranked 18th out of 25 student data points on the survey $(\mathrm{M}=$ $2.87, \mathrm{SD}=.834)$. During the 2020-2021 formation of classrooms, teachers were asked to rate students' parental involvement on a scale of 1 through 3 , with 1 indicating "not involved" and 3 indicating "very 
involved." Beyond these descriptors, there was no rubric, discussion, alignment, or metric for how these scores should be applied. Most respondents $(n=11,73 \%)$ rated this a 3 in terms of the data point's perceived usefulness during classroom formation.

Similarly, most respondents $(\mathrm{n}=11,73 \%)$ scored distance learning engagement as $1-3$ in its perceived usefulness $(\mathrm{M}=2.40, \mathrm{SD}=1.183)$. Its mean score ranked $22^{\text {nd }}$ out of 25 student data points, indicating an overall low consideration for the applicability of how students were engaged with distance learning to the process of forming new classrooms. A few months before teachers began the placement process, the Covid-19 pandemic shut down most in-person schooling across the county. GLC's district responded initially by having teachers call students on the phone to check in with them and while students worked asynchronously on printed packets. While the district's plan for distance learning was revised with scheduled, synchronous distance-learning components and internet-based group communication platforms, the earliest stages of the pandemic response had no such components. Teachers were asked to rate their student's level of distance learning engagement as high, medium, or low. No other rubric, metric, or discussions occurred to define what these ratings implied.

\section{Demographic and Categorical Data}

These objective student data points did not belong to any other category and were not based on any teacher assessment. However, all three of these data points were used by participants in the placement process at GLC during the 2019-2020 school year. While a student's enrollment in counseling services could be considered a type of intervention, it was placed in this section because the implications for classroom or teacher support vary widely according to the purpose for counseling services. These data points fell to the middle and lowest-ranked mean scores of perceived importance to student placement (see Table 5).

Table 5. Frequencies, means, and standard distributions of demographic and categorical data point rating responses

\begin{tabular}{|c|c|c|c|c|c|c|c|}
\hline Data Point & $\begin{array}{c}f \\
\text { Score } 1\end{array}$ & $\begin{array}{c}f \\
\text { Score } 2\end{array}$ & $\begin{array}{c}f \\
\text { Score } 3\end{array}$ & $\begin{array}{c}f \\
\text { Score } 4\end{array}$ & $\begin{array}{c}f \\
\text { Score } 5\end{array}$ & Mean & SD \\
\hline Counseling services & 1 & 1 & 4 & 5 & 4 & 3.67 & 1.175 \\
\hline Gender & 2 & 0 & 6 & 3 & 4 & 3.47 & 1.302 \\
\hline Wears glasses & 9 & 0 & 4 & 0 & 2 & 2.07 & 1.487 \\
\hline
\end{tabular}

The mean score for how educators perceived a student's enrollment in counseling services $(M=3.67$, $\mathrm{SD}=1.175)$ and their gender $(\mathrm{M}=3.47, \mathrm{SD}=1.302)$ ranked 13th and 14th out of 25 student data points. A student's enrollment in counseling services referred specifically to county or school district counseling services, although no specific instructions were given to indicate or differentiate between these cases. Most respondents marked counseling services middle to high, the majority of respondents $(\mathrm{n}=13,86 \%)$ scoring it between 3 and 5 .

Gender could be considered a preeminent consideration during the balancing of classrooms because the data cards used to form student groups are color-coded accordingly. The mean scores of the survey respondents ranked gender just under counseling status, 14th out of 25 student data points $(M=3.47$, $\mathrm{SD}=1.302$ ). The frequency distribution of gender scoring tends to the center, with most respondents ( $\mathrm{n}$ $=13,86 \%$ ) scoring it 3 or greater.

Whether a student wears glasses or not ranked last of all the student data points used during the 20192020 student placement cycle at GLC $(\mathrm{M}=2.07, \mathrm{SD}=1.486)$. Most respondents $(\mathrm{n}=9,60 \%)$ ranked it as "not useful." The remaining respondents $(n=4,26 \%)$ scored it as a 3 while two outliers marked glasses as "most important." 


\section{Open-Ended Responses}

The survey also asked respondents to address three open-ended questions to illuminate the context for the anchored scale responses by asking for areas of the placement process that participants felt were most and least helpful and/or productive and areas of improvement. Issues such as the reliability of subjective measures, the organization of placement meetings, the visual aids used during the placement meetings, micropolitical considerations, and the effects of the Covid-19 pandemic were themes that ran throughout the responses to all three open-ended questions after the process of thematic content analysis.

\section{Understanding meeting organization and processes critical for precise placements}

The systems and processes for managing the student placement process weighed heavily in many responses to the open-ended survey questions. Several educators, addressing different sections, noted the need for a more precise placement process that was also more efficient. One respondent wrote that a lack of structure made them do "double the work." Several respondents noted that placement meetings often involved irrelevant and needlessly lengthy discussions. The inability to come to decisions during the specified meeting time also caused consternation for many respondents. "It was not as productive when all parties did not understand the process," another respondent wrote. "It seems like we needed a clear step-by-step guide on how to go about building the classes with the data at hand." This confusion led to at least one group completely reshuffling the process mid-meeting because "they could not visualize how the process was supposed to work." Another respondent noted that the meetings "always felt rushed" due to such confusion.

Despite the problems related to meeting organization, respondents overwhelmingly noted that meeting in teams, specifically with the previous year's teachers, was beneficial. Collaboration was mentioned multiple times with regards to what aspects of the placement process proved helpful and productive. Multiple respondents stated things like, "It was helpful being able to discuss students with their previous teachers." Respondents went into further detail on this topic, saying that it was helpful to have the previous teachers present to ask questions, refine placement decisions, and discuss specific student interventions.

\section{Visual aids assist in the process}

The ability to visually observe, in real-time, the formation of classrooms was consistently mentioned in various sections of the open-ended survey responses. Clear, color-coded screens that showed the data point counts of each class inspired greater trust that classrooms were balanced between teachers. Respondents wrote comments like "having a color-coded spreadsheet made the process a lot more smooth" and "it was helpful to the grids...so we could see if the classes were balanced academically." Another wrote that "Having instant numbers on varies (sic) data points for students helped to balance classes more efficiently." Compared to having spreadsheet data immediately available, respondents observed that the pink and blue card system was akin to guessing.

\section{Be mindful when considering subjective data and measures}

One prevailing theme that ran through the responses was the distrust of some of the subjective data teachers used to place students. Because each grade level span was attempting to create internally heterogeneous, balanced classrooms between teachers, the issue of reliability came to the forefront in multiple survey answers. ELA and Math achievement was specifically mentioned, calling it "a personal criteria" and "the implementation of a person (sic) feelings." This lack of standardization, according to this respondent, "lead (sic) to many inequities." Respondents specifically mentioned that a lack of a grade-level alignment tool for ELA/Math achievement scores means that such data should be taken "with a grain of salt."

Likewise, teacher narrative comments were cited for being potentially skewed, calling them "a little bias." This same respondent suggested that administrators should preview teacher comments 
beforehand and coach teachers in eliminating bias language that is "based on emotion." One teacher wrote, "students often behave and/or achieve differently with other teachers or classroom environments. Sometimes one teacher's struggle does not manifest for the next (or vice versa)." This distrust of subjective data and teacher comments, however, did not indicate that teachers were hesitant to discuss students with their prior teachers. Instead, time and again, teachers noted that meeting with the previous teachers was helpful and necessary.

Finally, one respondent was concerned about the accuracy of some computer-based assessments because testing irregularities or skewed scores caused by students who may not have taken the assessment seriously. While few respondents specifically commented on this sort of occurrence, the relatively low rankings of digital tests in the previous section of the survey indicated that this might be a sentiment held by many educators. Another clue to this low ranking may be the different measures used at different grade spans, with one respondent stating that they gave low scores to STAR and PowerUp data points simply because they do not use those assessments in their grade level.

\section{Micro-political decision-making is a barrier to equitable placement}

Related to the respondents' concerns regarding biased, skewed, and subjective data were concerns about micro-political decisions that caused potential equity issues. Concerns were raised about making roster changes according to "arbitrary criteria" to accommodate "best fit or past family relationships." According to this respondent, placing students according to past family relationships created a "tracking system...which reduced equity." Likewise, another respondent noted that "the idea that you previously had the family should not be highly considered." They noted that administration should take a leading role in setting the culture and expectations that would curtail this sort of activity.

Multiple respondents noted that off-the-shelf placement software could potentially alleviate equity issues related to the micro-political posturing and biased data. Another respondent noted that such software would also make initial class building and adjustments more efficient. One respondent stated that such software could prevent "teachers favoring their friends", thereby preventing "inequitable class placements." Another answer to this issue provided by respondents would be to have the previous teachers' pre-make balanced classroom assignments and randomly assign them to a teacher. Doing this would likewise serve to eliminate favoritism and prevent teachers from lobbying for or making biased assignments.

\section{Covid-19 pandemic-related concerns impact feelings of trust in the classroom placement process}

Distance learning and the Covid-19 pandemic loomed over many of the survey responses. The visual, spreadsheet data system that many respondents reacted positively to was initially conceived to overcome the barriers associated with remote, online meetings. Equity was a concern for those measuring students' distance learning engagement "because all families did not have the same access i.e. tech and internet last year." Lastly, multiple respondents noted their frustration with having much of the placement work undone by the district to accommodate their mandated bifurcated, distancelearning school day schedule. "Due to Covid and all the changes between classes," one respondent wrote, "the hard work we put in felt wasted."

\section{DISCUSSION and CONCLUSION}

Open-ended survey data often explained why certain student data points were rated as highly applicable to the student placement process and why some data were regarded as less valuable. For example, student IEP status, ELPAC level, and 504 status, the three most useful student data points, represent what one respondent called "legally binding" designations that require the educator to adjust instruction according to a specific set of parameters to meet student needs. This mirrors findings in the literature in how student data points are prioritized by decision-makers (Datnow \& Park, 2018; Paufler \& AmreinBeardsley, 2014). Several other survey respondents wrote that the focus on ELPAC level was a 
productive and helpful part of the placement process "because it allows the time to consider what accommodations (even those that are universal) and/or modifications the student needs." The GLC student population consists of $25.9 \%$ English Learners, above the California state average of $18.6 \%$ (CDE n.d.). The fact that ELPAC status was rated so highly indicates that this substantial population of students is considered critical to the formation of classrooms, and their effect on classroom-level instruction is considered substantial in the eyes of the educators at the research school. This is an encouraging situation regarding student equity. In this case, the data used to group students into the classrooms translated into teacher preparation for meeting their needs.

Data measures were not seen as equally reliable, however. While ELA and Math achievement levels were important for survey respondents, many made note that a lack of site or grade-level scoring alignment caused doubts as to whether such data were valid. Further complicating the measurement of math and ELA achievement are the respondents' views on the various available computer-based assessments. For example, STAR and Lexia levels, while inherently standardized in delivery and scoring, were rated lower than math and ELA level of achievement supplied by teachers with regards to their usefulness. This is due in part to the multiple computer-based measures that differ across grade levels. Mandinach \& Gummer (2016) state that educators must understand the context for data during their decision-making process. For many of these standardized assessments, the context of the test simply did not apply to placement processes involving their grade level.

The greatest hindrance in an equity-based student placement process was the meetings themselves. While prioritizing student data points was important, many respondents stated the procedures were illdefined in intent and process. How placement decisions are facilitated has important ramifications for the ways teachers communicate, advocate, and use information (Park et al., 2017; Paufler \& AmreinBeardsley, 2014; Sleenhof et al., 2019). Therefore, creating and communicating a clear set of steps is critical to ensuring that students can be placed in a classroom situation that is appropriate for their needs. To ensure equitable decision-making, the principal must emphasize asset-based approaches centered around the team's accepted belief that student attributes are not fixed determinations but rather guideposts to drive instruction (Paufler \& Amrein-Beardsley, 2014). Such procedures need to encourage orderly participant interaction, something the literature and the survey results support (Paufler \& Amrein-Beardsley, 2014). The literature and survey responses also indicate that improved support is needed to create an informed, shared vision for the ways student data are used before the placement of students begins (Mandinach \& Gummer, 2016; Park et al., 2017; Sleenhof et al., 2019).

Lastly, such meetings must include a shared visual component that creates a shared understanding of classroom demographics. Survey respondents overwhelmingly stated that a real-time, side-by-side visual representation of classroom populations helped create fair, balanced, and heterogeneous classrooms. Clear, organized, graphically-based data allowed stakeholders to make better-informed decisions with greater confidence (Sleenhof et al., 2019).

\section{Elementary student classroom placement relates to issues of educational equity}

The process of assigning elementary students to their next classroom relates to issues of educational equity in two significant ways. First, classroom placement has a significant effect on the trajectory of students' education. Several researchers noted that the deployment of resources and interventions is dependent on classroom placement, including the experience and quality of the teacher being assigned to a given group of students (Bosworth \& Li, 2013; Burns \& Mason, 1995; Kalogrides et al., 2013; Sleenhof et al., 2019; St. John, 2014). This was similarly reflected in the survey data. Multiple respondents noted concerns that micropolitical decisions had a noticeable effect on where students would be placed, creating a de facto tracking system that potentially overrode the intention of creating balanced, heterogeneous groups.

Second, how data are used during the student placement procedures is tied directly to equity. Multiple researchers noted that the way student data are gathered, prioritized, discussed, and utilized during the 
placement process has significant implications for school equity (Datnow \& Park, 2018; Kalogrides et al., 2013; Mandinach \& Gummer, 2016; Marsh \& Farrell, 2015; Park et al., 2017). Survey data gathered in this research project mirrored this assertion as well. Respondents highly rated the importance of student data points that necessitated specific interventions, like SPED or English-Learner status. Survey respondents also noted that the legal and ethical requirements to make appropriate accommodations for students were considered during the placement process. Furthermore, they noted that some data points, while potentially useful, were suspect because teachers within and between grade levels did not similarly calibrate their grading. Several respondents noted that teacher comments had the potential to be biased, and therefore discounted or ignored such student data during their decision-making process.

\section{Improving the classroom placement process to promote equity and student achievement}

In order to promote more equitable practices during the placement process, such procedures first need to be transparent, well-developed, and clearly explained to the participants. Researchers noted on several occasions that how placement meetings were organized and carried out affected how students were discussed and how decisions were made (Burns \& Mason, 1998; Paufler \& Amrein-Beardsley, 2014; Sleenhof et al., 2019). Administrative training and credentialing programs are well-positioned to address this since principals are often central to managing these procedures. Nevertheless, principals currently receive limited training in the formation of classrooms or student placement (Paufler \& Amrein-Beardsley, 2014). Multiple respondents in the survey similarly communicated a desire for a transparent, efficient process for student placement that reduced the effects of educator bias and maximized student well-being.

In terms of general systems theory (Sauter, 2017; Vornberg, 2013), the process for moving an elementary student from one class to the next needs to determine what input (student data) is most important to the process and how the subsystems and elements within that process are organized to produce the desired output (balanced, heterogeneous classrooms). School districts are in an excellent position to develop these systems yet have often not done so (Paufler \& Amrein-Beardsley, 2014). Therefore, creating a standardized, district-wide placement system that meets the needs of local stakeholders would go a long way towards rectifying potential missteps and preventing bias from interfering with equitable student placement.

With regards to site-level considerations, stakeholders and decision-makers can make several first steps to improve their processes. Before placement begins, educators on the site need to calibrate their grading and achievement data within and between grade levels. Achievement scores rank highly in importance both in the research literature and in this project's survey data. However, concerns about the quality of such data remain. Regular calibration of such data would help to rectify those worries and improve stakeholder confidence. Next, site leadership must promote specific language and attitudes that set a tone for equity during these procedures. Systems that explicitly espouse and engage in asset-based thinking are better equipped to produce holistic decisions that promote inclusivity from all stakeholders (Datnow \& Park, 2018; Sleenhof et al., 2019).

Lastly, stakeholders would be well-served by aligning their placement procedures to existing MTSS systems. This would promote a common language between decision-makers and thus help to calibrate and prioritize data. An example of this sort of MTSS alignment could be behavioral data. Behavioral data rate highly in the literature and with this research project's survey respondents regarding its impact on placement decisions (Paufler \& Amrein-Beardsley, 2014). Using language and data drawn directly from MTSS behavior systems, such as the placement of students in one of three behavior intervention tiers, would help standardize the way behavior data are addressed and disentangle teacher bias from the discussion. By centering placement procedures in terms of the required interventions necessary for responding to students' needs equitably and effectively, an asset-based approach is reinforced and promoted during the creation of heterogeneous, balanced classrooms. See Table 6 for an overview of a proposed elementary student placement process modeled after Conzemius and O'Neil (2014) and Figure 2 for a decision-making flowchart for the placement meeting process. The process was developed 
based on the findings of this study and the literature delineating how such systematic, equity-based placement procedures might be undertaken to further this action research or considered in other similar contexts.

Table 6. Action plan for elementary classroom placement process

\begin{tabular}{|c|c|c|c|c|}
\hline Phases & Action Steps & Timeline & Persons Responsible & Leader Considerations \\
\hline \multirow[t]{4}{*}{$\begin{array}{l}\text { Phase } 1 \text { - } \\
\text { Before the } \\
\text { placement } \\
\text { meeting }\end{array}$} & $\begin{array}{l}\text { Calibrate grading } \\
\text { within and } \\
\text { between grade- } \\
\text { level teams }\end{array}$ & Aug- Dec & $\begin{array}{l}\text { Grade Level Teams will } \\
\text { meet to define how } \\
\text { achievement levels will } \\
\text { be measured. } \\
\text { Administrators will } \\
\text { facilitate meetings and } \\
\text { provide in-service } \\
\text { teaching as required. }\end{array}$ & $\begin{array}{l}\text { Maintaining cohesion in ELA and Math } \\
\text { scoring is important for fomenting } \\
\text { confidence in the placement process and for } \\
\text { that formation of balanced classes. }\end{array}$ \\
\hline & $\begin{array}{l}\text { Adjust procedures } \\
\text { and review site's } \\
\text { guiding principles } \\
\text { for placement }\end{array}$ & Dec-Jan & $\begin{array}{l}\text { Administrators will } \\
\text { facilitate team meetings } \\
\text { to adjust placement } \\
\text { protocols using } \\
\text { feedback from previous } \\
\text { year's feedback. }\end{array}$ & $\begin{array}{l}\text { This step is critical to maintain the } \\
\text { continued integrity and applicability of the } \\
\text { procedures to current site conditions and } \\
\text { stakeholders. The site's guiding principles } \\
\text { for placement will be reviewed to ensure } \\
\text { relevance. }\end{array}$ \\
\hline & $\begin{array}{l}\text { Gather documents } \\
\text { and data }\end{array}$ & Feb-Mar & $\begin{array}{l}\text { Teacher teams will } \\
\text { work together to ensure } \\
\text { they have all the } \\
\text { necessary student data } \\
\text { points easily available } \\
\text { and ready. }\end{array}$ & $\begin{array}{l}\text { While not all the necessary year-end data } \\
\text { will be finalized, having a common digital } \\
\text { storehouse or repository ready for data } \\
\text { entry will ease and quicken the following } \\
\text { steps. }\end{array}$ \\
\hline & $\begin{array}{l}\text { Enter appropriate } \\
\text { data points into } \\
\text { spreadsheet or } \\
\text { other visual } \\
\text { workspace }\end{array}$ & $\begin{array}{l}\text { Late Mar - } \\
\text { Early Apr }\end{array}$ & $\begin{array}{l}\text { Teachers will enter the } \\
\text { data for their students. }\end{array}$ & $\begin{array}{l}\text { The nature of this step depends on how the } \\
\text { site's teams are sharing information in a } \\
\text { visual format that facilitates classroom } \\
\text { balance. }\end{array}$ \\
\hline \multirow[t]{5}{*}{$\begin{array}{l}\text { Phase } 2 \text { - } \\
\text { During the } \\
\text { placement } \\
\text { meeting }\end{array}$} & $\begin{array}{l}\text { Review site's } \\
\text { guiding principles } \\
\text { for placement }\end{array}$ & Mid-Apr & $\begin{array}{l}\text { Grade level team and } \\
\text { meeting facilitator }\end{array}$ & $\begin{array}{l}\text { A brief review of the site's principles } \\
\text { regarding placement will serve to remind } \\
\text { the team of their purpose with special } \\
\text { emphasis focused on student } \\
\text { achievement and equity }\end{array}$ \\
\hline & $\begin{array}{l}\text { Place students } \\
\text { receiving special } \\
\text { services (SPED, } \\
504, \text { non-speech) }\end{array}$ & & $\begin{array}{l}\text { Grade level team and } \\
\text { meeting facilitator }\end{array}$ & $\begin{array}{l}\text { Begin placing students with IEPs or } 504 \\
\text { plans. }\end{array}$ \\
\hline & Place EL Students & & $\begin{array}{l}\text { Grade level team and } \\
\text { meeting facilitator }\end{array}$ & $\begin{array}{l}\text { Maintain a balance of ELPAC levels within } \\
\text { classrooms }\end{array}$ \\
\hline & $\begin{array}{l}\text { Place students on } \\
\text { Tier } 1 \text { behavior } \\
\text { plan }\end{array}$ & & $\begin{array}{l}\text { Grade level team and } \\
\text { meeting facilitator }\end{array}$ & $\begin{array}{l}\text { During placement, monitor ELA and Math } \\
\text { achievement levels in each of the forming } \\
\text { classes and adjust as required to maintain } \\
\text { balance between groups }\end{array}$ \\
\hline & $\begin{array}{l}\text { Place students on } \\
\text { Tier } 2 \text { behavior } \\
\text { plan }\end{array}$ & & $\begin{array}{l}\text { Grade level team and } \\
\text { meeting facilitator }\end{array}$ & $\begin{array}{l}\text { During placement, monitor ELA and Math } \\
\text { achievement levels in each of the forming } \\
\text { classes and adjust as required to maintain } \\
\text { balance between groups. }\end{array}$ \\
\hline
\end{tabular}




Give tentative
initial lists to site
administrator

Place students of
Tier 3 behavior
plan

Give tentative initial lists to site plan
Grade level team and meeting facilitator

Administrator, grade level team and meeting facilitator, along with behavior intervention specialists or other site and district experts as appropriate for context
Site administrator will fine tune class lists to improve balance and heterogeneity, and then move to the next step of placing those students needing Tier 3 behavior supports.

Students identified as needing Tier 3 behavior supports will need to be strategically placed so as to maintain balance, heterogeneity, with emphasis on student success.

\begin{tabular}{|c|c|c|c|c|}
\hline \multirow[t]{4}{*}{$\begin{array}{l}\text { Phase } 3 \text { - } \\
\text { After the } \\
\text { placement } \\
\text { meeting }\end{array}$} & $\begin{array}{l}\text { Collect and } \\
\text { analyze participant } \\
\text { reflection data }\end{array}$ & Late April & $\begin{array}{l}\text { Administrator, meeting } \\
\text { facilitator }\end{array}$ & $\begin{array}{l}\text { Use reflection or survey tool to gather } \\
\text { teacher feedback on the placement process } \\
\text { in order to facilitate the improvement of } \\
\text { future placement cycles. }\end{array}$ \\
\hline & $\begin{array}{l}\text { Assign teachers to } \\
\text { classes }\end{array}$ & June-July & Administrator & $\begin{array}{l}\text { This step may need to be adjusted based on } \\
\text { Tier } 3 \text { student interventions and specific } \\
\text { teacher skill sets and/or temperaments to } \\
\text { ensure an equitable placement for such } \\
\text { students. }\end{array}$ \\
\hline & $\begin{array}{l}\text { Publish class lists } \\
\text { with teacher } \\
\text { assignments }\end{array}$ & $\begin{array}{l}\text { Late July- } \\
\text { Early Aug }\end{array}$ & Administrator & $\begin{array}{l}\text { Class lists are published for staff and } \\
\text { parents. }\end{array}$ \\
\hline & $\begin{array}{l}\text { Teachers meet to } \\
\text { review previous } \\
\text { teacher comments }\end{array}$ & Early Aug & Administrator, Teachers & $\begin{array}{l}\text { Before school begins, the Administrator } \\
\text { will schedule and plan a series of brief } \\
\text { meetings or allocate planning time for } \\
\text { teachers to discuss students. Special } \\
\text { attention will be given to share effective } \\
\text { strategies for Tier } 2 \text { and Tier } 3 \\
\text { interventions. }\end{array}$ \\
\hline
\end{tabular}

\section{Meeting Facilitation Considerations}

It may be helpful to have a placement meeting facilitator who can guide the process so the teacher teams can focus on assigning the appropriate student at each step and monitor the balance between the classes being formed in real-time. Teachers should take turns assigning a student to each group to ensure that classes are appropriately heterogeneous and balanced. The facilitator's task will be to update any visual tracking tool or spreadsheet, and ensure the team is abiding by the site's guiding principles.

Students requiring Tier 3 interventions will require special consideration with regards to equitable placements. The administrator may want to match interventions to particular teacher temperaments and skill sets; however, this process is premised on the idea that each teacher should be prepared and able to provide every student with the appropriate interventions. The administrator making final decisions with regards to matching classes and teachers would be advised to consider and prepare appropriate supports for teachers who may need assistance meeting the needs of their Tier 3 students during the school year.

Before the school year begins, it is advisable that teacher teams meet to discuss Tier 2 and Tier 3 intervention students with the previous year's teachers and appropriate specialists. This meeting can be done formally or informally depending on time available and circumstances at the school site. These meetings should focus on discussing effective interventions and strategies for those students, emphasizing asset-based approaches. 


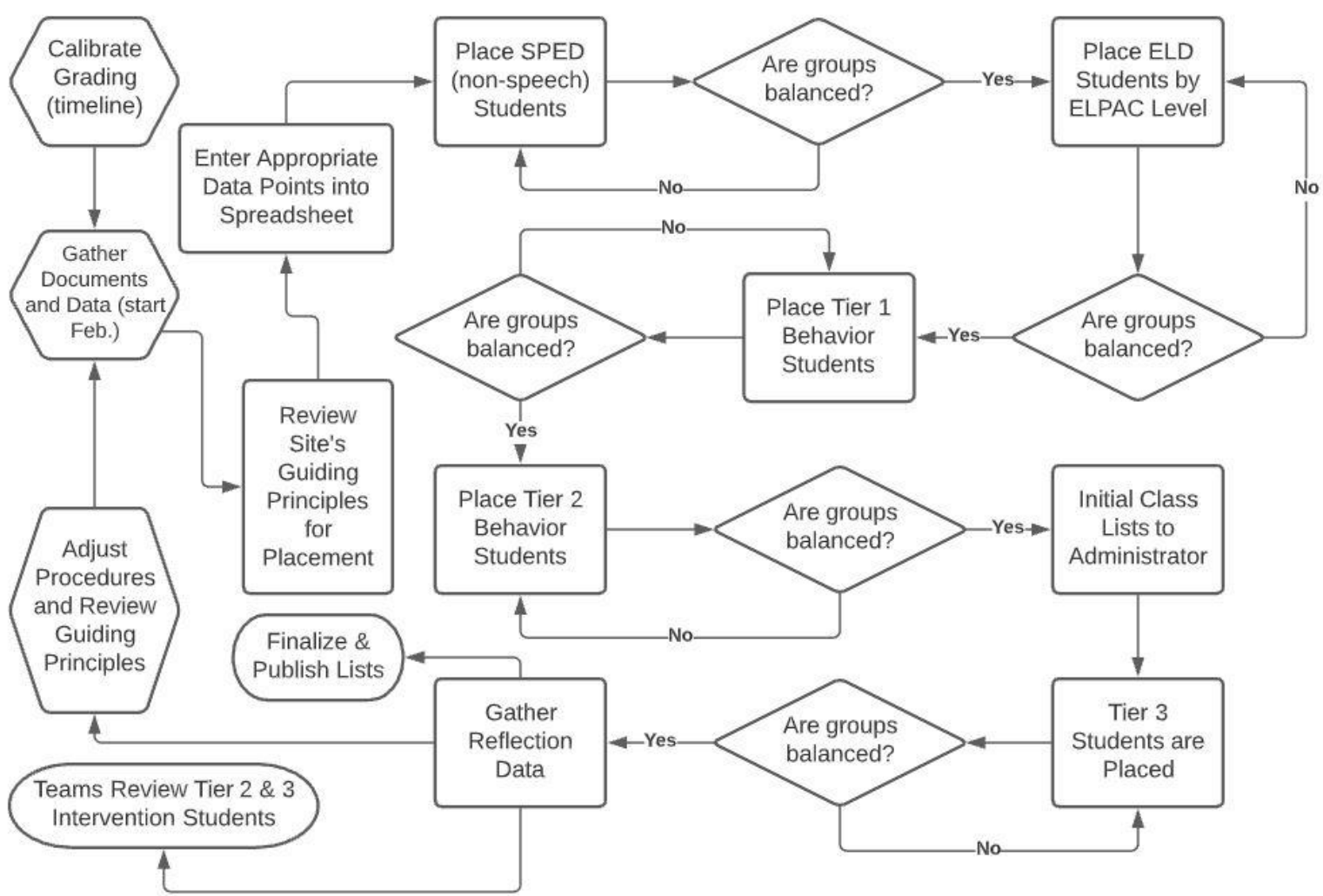

Figure 2. Placement meeting procedure decision-making flowchart

\section{Limits of the Study}

Because this research project focused on a single school site case, the study was limited in scope and number of respondents. Future research could be conducted to more comprehensively examine the procedures for student placement procedures across multiple schools within a district. A larger sample size of respondents would also more clearly delineate trends and variations in educator attitudes. Adding demographic data to future surveys would better demonstrate how teachers of lower elementary school students are differentiated in their attitudes and priorities from upper elementary teachers. This could possibly reveal trends within educator demographic groups, including years of experience, socioeconomics, gender, or race.

Finally, future research would do well to investigate how improving placement procedures along the lines presented in this research study correlate to improved student achievement and equity at the school site.

\section{Ethics and Conflict of Interest}

We, as the authors of this article, have acted in accordance with ethical rules at all stages of the research, and there is no conflict of interest among the authors.

\section{REFERENCES}

Bosworth, R., \& Li, H. (2013). Patterns in student assignment to elementary school classrooms. Education Policy Analysis Archives, 21(51), 1-26. https://doi.org/10.14507/epaa.v21n51.2013

Buffum, A. G., Mattos, M., \& Malone, J. (2018). Taking action: A handbook for RTI at work. Solution Tree Press.

Burns, R. B., \& Mason, D. A. (1995). Organizational constraints on the formation of elementary school classes. American Journal of Education, 103(2), 185-212.

Burns, R. B., \& Mason, D. A. (1998). Class formation and composition in elementary schools. American Educational Research Journal, 35(4), 739-772. https://doi.org/10.2307/1163465 
California Department of Education (n.d.) [Redacted] Charter Summary | California School Dashboard. https://www.caschooldashboard.org/reports/[identifier redacted]

Caws, P. (2015). General systems theory: Its past and potential. Systems Research \& Behavioral Science, 32(5), 514-521. https://doi.org/10.1002/sres.2353

Conzemius, A., \& O'Neill, J. (2014). The handbook for SMART school teams: Revitalizing best practices for collaboration $\left(2^{\text {nd }}\right.$ ed.). Solution Tree Press.

Datnow, A., \& Park, V. (2018). Opening or closing doors for students? Equity and data use in schools. Journal of Educational Change, 19(2), 131-152. https://doi.org/10.1007/s10833-018-9323-6

DePaolo, C. A., \& Wilkinson, K. (2014). Get your head into the clouds: Using word clouds for analyzing qualitative assessment data. TechTrends, 58(3), 38-44. https://doi.org/10.1007/s11528-014-0750-9

DuFour, R., DuFour, R., Eaker, R., Many, T. W., \& Mattos, M. (Eds.). (2016). Learning by doing: A handbook for professional learning communities at work ( $3^{\text {rd }}$ ed.). Solution Tree Press.

Fincham J. E. (2008). Response rates and responsiveness for surveys, standards, and the Journal. American Journal of Pharmaceutical Education, 72(2), 1-3 (Article 43). https://doi.org/10.5688/aj720243

Johnson, B., \& Christensen, L. B. (2017). Educational research: Quantitative, qualitative, and mixed approaches (6 $6^{\text {th }}$ ed.). SAGE Publications

Kalogrides, D., Loeb, S., \& Béteille, T. (2013). Systematic sorting: Teacher characteristics and class assignments. Sociology of Education, 86(2), 103-123. https://doi.org/10.1177/0038040712456555

Mandinach, E. B., \& Gummer, E. S. (2016). What does it mean for teachers to be data literate: Laying out the skills, knowledge, and dispositions. Teaching and Teacher Education, 60, 366-376. https://doi.org/10.1016/j.tate.2016.07.011

Marsh, J. A., \& Farrell, C. C. (2015). How leaders can support teachers with data-driven decision making: A framework for understanding capacity building. Educational Management Administration \& Leadership, 43(2), 269-289. https://doi.org/10.1177/1741143214537229

Park, V., St. John, E., Datnow, A., \& Choi, B. (2017). The balancing act: Student classroom placement routines and the uses of data in elementary schools. Journal of Educational Administration, 55(4), 390-406. https://doi.org/10.1108/JEA$\underline{09-2016-0098}$

Paufler, N. A., \& Amrein-Beardsley, A. (2014). The random assignment of students into elementary classrooms: Implications for value-added analyses and interpretations. American Educational Research Journal, 51(2), 328-362. https://doi.org/10.3102/0002831213508299

Sauter, V. L. (2017, January 25). Systems Analysis Current Page. http://www.umsl.edu/ sauterv/analysis/intro/system.htm

Sleenhof, J. P. W., Koopman, M., Thurlings, M. C. G., \& Beijaard, D. (2019). An exploratory study into teachers' beliefs and experiences about allocating students. Teaching and Teacher Education, 80, 94-105. https://doi.org/10.1016/j.tate.2019.01.007

St. John, E. M. (2014). Understanding the factors that influence the grouping and assignment of students to elementary classrooms, (Unpublished doctoral dissertation). University of Washington, United States. https://digital.lib.washington.edu:443/researchworks/handle/1773/26214

Unified School District. (n.d.) [Redacted] Charter school / Homepage. Location redacted for confidentiality.

Vornberg, J. A. (2013). Systems theory. In B. Irby, G. H. Brown, R. LaraAiecio, \& S. A. Jackson (Eds.), Handbook of Educational Theories (pp. 805-813). Information Age Publishing, Incorporated. http://ebookcentral.proquest.com/lib/csufresno/detail.action?docID $=3315873$ 